\title{
Crystallisation of strontium sulphates from Si-bearing aqueous solutions
}

\author{
Carlos M. Pina*, Álvaro Tamayo \\ Department of Crystallography and Mineralogy, Complutense University of Madrid, c/José Antonio Novais 2, Madrid E-28040, Spain
}

Received 27 June 2011; accepted in revised form 18 June 2012; available online 2 July 2012

\begin{abstract}
The crystallisation behaviour in the $\mathrm{SrCl}_{2}-\mathrm{Na}_{2} \mathrm{SO}_{4}-\mathrm{H}_{2} \mathrm{O}$ system at room temperature is strongly modified by the presence of dissolved silicon. Homogeneous nucleation experiments show that silicon inhibits the formation of celestite while promoting the precipitation of $\mathrm{SrSO}_{4} \cdot 0.5 \mathrm{H}_{2} \mathrm{O}$ and an amorphous phase. Interfacial free energies for celestite have been calculated for increasing silicon concentrations from measurements of induction times for homogeneous nucleation. The slight increase in the interfacial free energies confirms that dissolved silicon is an inhibitor of celestite nucleation. In addition, dissolved silicon has striking morphological effects. Celestite grown in the presence of silicon typically shows rounded and peanut-like morphologies formed by numerous disoriented crystals. The anomalous celestite morphologies and the increase in both induction times and interfacial free energies reveal a complex interaction between silicic acids and celestite surfaces. In situ atomic force microscopy (AFM) was used to study in detail the effect of dissolved silicon on the growth of celestite (001) faces. AFM observations show that the presence of silicon increases the growth velocity of a first monolayer on the celestite (001) face. However, once such a first monolayer is formed, no further multilayer growth is observed. Height and friction AFM images show clear differences in contrast between the first monolayer and the celestite (001) substrate, revealing differences in composition and/or structure. High-resolution AFM images of the first monolayer show patterns consistent with the celestite (001) surface lattice, indicating that a limited amount of silicon can be incorporated into the celestite structure. Therefore, both the observed inhibition of nucleation and growth of celestite and the changes in crystal morphologies can be partially related to the formation of self-limiting Si-bearing celestite monolayers.
\end{abstract}

(c) 2012 Elsevier Ltd. All rights reserved.

\section{INTRODUCTION}

Celestite $\left(\mathrm{SrSO}_{4}\right)$ and barite $\left(\mathrm{BaSO}_{4}\right)$ are two important marine minerals linked to the strontium and barium biogeochemical cycles, which are also used as paleoproxies (e.g. Kesler and Jones, 1981; Paytan et al., 1998, 2004). They are ubiquitous in suspended matter in the oceans even though most seawater is undersaturated with respect to both celestite and barite (Chow and Goldberg, 1960; Church and Wolgemuth, 1972; Monnin et al., 1999; Rushdi et al., 2000). The presence of celestite in the oceanic water column can be explained by the biological activity of

\footnotetext{
* Corresponding author.

E-mail address: cmpina@geo.ucm.es (C.M. Pina).
}

acantharians, a unique and widespread group of protozoans, which construct their exoskeletons with this mineral (Odum, 1951; Bernstein et al., 1987). On the contrary, no major planktonic group can directly induce the precipitation of barite (Bernstein and Byrne, 2004). Furthermore, the processes involved in the formation of marine barite from undersaturated seawater with respect to this mineral are not yet completely understood. This has been referred to in the literature as the "barite paradox" (Monnin and Cividini, 2006 and references therein).

To solve the "barite paradox", Bernstein et al. (1992) and Bernstein et al. (1998) proposed that the formation of marine barite is related to the previous precipitation of celestite by acantharians, which acts as a precursor phase. Celestite crystals in the acantharian micro-exoskeletons 
contain up to $10 \%$ barium (Bernstein et al., 1992). When these organisms die, their skeletons dissolve, leading to a local increase in barium in the seawater that can result in the precipitation of barite with strontium contents that may exceed 20\% (Dehairs et al., 1980). According to this mechanism, the formation of large amounts of marine barite involves both organic and inorganic processes: (i) biologically-controlled precipitation of $\mathrm{Ba}$-celestite, (ii) dissolution of Ba-celestite releasing Ba into the seawater, and (iii) inorganic precipitation of $\mathrm{Sr}$-barite. Therefore, the functioning of such a mechanism would imply that the strontium and barium biogeochemical cycles are related.

Celestite and barite are not only proxies of strontium and barium marine geochemistry. The distribution of both minerals seems to also be linked to dissolved silica and siliceous plankton in the oceans. In the case of suspended barite, this linkage was suggested by the similarity of dissolved silicon and barium profiles in the water column (Chan et al., 1977). In addition, it has been reported that opal and siliceous materials are frequently associated with barite in sediments, indicating that silica surfaces may promote the heterogeneous nucleation of this mineral (Bishop, 1988).

For marine celestite, the correlation with the presence of different forms of silica seems to be more complex and is probably related to ecological relationships between acantharians and radiolarians (Bernstein et al., 1992). Acantharians and radiolarians belong to the same Phylum of planktonic microorganisms, and they share ecological niches and living strategies. Acantharians construct their skeletons with celestite, and radiolarians exclusively use silica. Interestingly, some radiolarians (from the Family Collosphaeridae) also contain tiny celestite granules within their siliceous shells whose function is not known (Hollande and Martoja, 1974). Bernstein et al. (1992) speculated that some radiolarians might use acantharians as a food source, leading to a rapid dissolution of their celestite skeletons after ingestion. Alternatively, it is a reasonable speculation that some radiolarians incorporate part of the acantharians' celestite skeletons to form their internal granules. Confirming a strong relationship between acantharians and radiolarians within the food chain, along with both the impact of acantharians in the biogeochemical cycle of barium and the frequent opal-barite association in sediments, would indicate that the distributions of strontium, barium and silica in the oceans are not independent. In this context, a precise knowledge of the effects of dissolved silicon and particulate silica on the crystallisation of both celestite and barite is essential to better understand the functioning and potential coupling of the strontium, barium and silica biogeochemical cycles. However, there is a lack of systematic experimental work to evaluate the effect of silica on the nucleation and crystal growth behaviour of celestite and barite.

In this paper, we present a detailed study of the crystallisation behaviour of the $\mathrm{SrCl}_{2}-\mathrm{Na}_{2} \mathrm{SO}_{4}-\mathrm{H}_{2} \mathrm{O}$ system in the presence of dissolved silicon with concentrations ranging from 2 to $600 \mathrm{ppm}$, i.e. a concentration range that includes those of typical shallow and deep seawaters, marine sediments and possible siliceous marine microenvironments
(Siever, 1957; Iler, 1979; Isshiki et al., 1991 and references therein; Von Damm, 1995). The aim of our investigation is threefold: (i) to quantify the effect of dissolved silicon on the nucleation kinetics of strontium sulphates in a wide range of concentrations; (ii) to analyse changes in the size and morphology of celestite crystals induced by the presence of dissolved silicon during the early stages of crystallisation; and (iii) to study the effect at the nanoscale of dissolved silicon on the growth of celestite (001) surfaces.

\section{EXPERIMENTAL PROCEDURE}

\subsection{Precipitation experiments}

Four series of precipitation experiments were conducted at room temperature by mixing solutions of $10 \mathrm{~cm}^{3}$ of $\mathrm{Na}_{2} \mathrm{SO}_{4}+0.021$ to $1.16 \mathrm{~cm}^{3}$ of $\mathrm{Na}_{2} \mathrm{SiO}_{3}$ with $10 \mathrm{~cm}^{3}$ of $\mathrm{SrCl}_{2}$. The solutions were prepared from $\mathrm{Na}_{2} \mathrm{SO}_{4}, \mathrm{Na}_{2} \mathrm{SiO}_{3}$ and $\mathrm{SrCl}_{2}$ reagent-grade chemicals and deionised water (Milli-Q Millipore; resistivity $18 \mathrm{M} \Omega \mathrm{cm}$ ). Table 1 (columns 2-6) shows the concentrations of the solutions after mixing, the initial total $\mathrm{Si}$ content in the aqueous solutions, the calculated $\mathrm{pH}$ values and the supersaturations with respect to celestite. The expression used to calculate supersaturation with respect to celestite was:

$\beta_{\text {celestite }}=\frac{a\left(\mathrm{Sr}^{2+}\right) \cdot a\left(\mathrm{SO}_{4}^{2-}\right)}{K_{\text {sp }, \text { celestite }}}$

where $K_{\text {sp,celestite }}=10^{-6.63}$ is the solubility product for celestite and $a\left(\mathrm{Sr}^{2+}\right)$ and $a\left(\mathrm{SO}_{4}^{2-}\right)$ are the activities of $\mathrm{Sr}^{2+}$ and $\mathrm{SO}_{4}^{2-}$ ions, respectively. These ionic activities were calculated using the PHREEQC computer code and the PHREEQC.DAT database (Parkhurst and Appelo, 1999). As can be seen in Table 1 , the increase in the $\mathrm{pH}$ values of the solutions when the $\mathrm{Si}$ content increases from 12 to $597 \mathrm{ppm}$ is low. Thus, a significant effect of the initial $\mathrm{pH}$ of the solutions on the nucleation kinetics is not expected. After mixing the solutions, precipitation is not instantaneous. Nucleation was detected when turbidity was observed after mixing the solutions. The measurement of the time elapsed until turbidity is observed visually allowed us to determine induction times for homogeneous nucleation. The maximum expected error in the determination of induction times using this method is around $8 \%$. Immediately after precipitation, solutions were filtered with quantitative filter paper with a pore size of 7-9 $\mu \mathrm{m}$ (Filter-Lab 1242) and standard filter paper (Filter-Lab 1305). Then, the precipitates were dried at room temperature. The precipitates were studied using X-ray diffraction to determine the solid phases that formed. The diffractometers used were a Philips X'Pert PRO MRD and a Siemens D-500, both equipped with $\mathrm{Cu}$ X-ray sources. A selected number of precipitates were also studied by scanning electron microscopy (SEM). The apparatus used was a JEOL JSM 6400 with a voltage of $40 \mathrm{kV}$. SEM images allowed us to observe the morphologies of the crystals previously identified by X-ray diffraction. The silicon content of the precipitates was measured by a Link-analytical EDX. 
Table 1

Precipitation experiments: concentration of the reactants, initial total silicon concentration, calculated $\mathrm{pH}$ of the solutions, supersaturation with respect to celestite, induction time for homogeneous nucleation and identified phases in the precipitates $\left(\mathrm{C}:\right.$ celestite; $\mathrm{H}: \mathrm{SrSO}_{4} \cdot 0.5 \mathrm{H}_{2} \mathrm{O}$; A: amorphous phase; question marks indicate unreliable phase identification).

\begin{tabular}{|c|c|c|c|c|c|c|c|}
\hline Experiment number & $\mathrm{Na}_{2} \mathrm{SO}_{4}(\mathrm{mmol} / \mathrm{l})$ & $\mathrm{SrCl}_{2}(\mathrm{mmol} / \mathrm{l})$ & {$[\mathrm{Si}]_{\text {tot }}(\mathrm{ppm})$} & $\mathrm{pH}$ & Supersaturation $\beta_{\text {celestite }}$ & Time $(s)$ & Phase \\
\hline $\mathrm{C} 1-0$ & 25.00 & 25.00 & 0 & 7.07 & 165.1 & 56 & $\mathrm{C}$ \\
\hline C1-1 & 24.97 & 24.97 & 12 & 10.00 & 164.9 & 73 & C \\
\hline $\mathrm{C} 1-2$ & 24.95 & 24.95 & 23 & 10.17 & 164.7 & 79 & $\mathrm{C}$ \\
\hline $\mathrm{C} 1-3$ & 24.89 & 24.89 & 46 & 10.34 & 164.3 & 93 & $\mathrm{C}$ \\
\hline $\mathrm{C} 1-4$ & 24.87 & 24.87 & 57 & 10.39 & 164.1 & 143 & $\mathrm{C}$ \\
\hline $\mathrm{C} 1-5$ & 24.82 & 24.82 & 80 & 10.47 & 163.6 & 150 & $\mathrm{C}$ \\
\hline $\mathrm{C} 1-6$ & 24.79 & 24.79 & 91 & 10.50 & 163.4 & 114 & $\mathrm{C}$ \\
\hline $\mathrm{C} 1-7$ & 24.76 & 24.76 & 102 & 10.52 & 163.2 & 107 & $\mathrm{C}$ \\
\hline $\mathrm{C} 1-8$ & 24.74 & 24.74 & 115 & 10.55 & 163.0 & 110 & $\mathrm{C}$ \\
\hline C1-9 & 24.69 & 24.69 & 136 & 10.59 & 162.6 & 73 & $\mathrm{~A}+\mathrm{C}$ \\
\hline $\mathrm{C} 1-10$ & 24.61 & 24.61 & 170 & 10.63 & 162.0 & 51 & $\mathrm{~A}+\mathrm{C}$ \\
\hline $\mathrm{C} 1-11$ & 24.36 & 24.36 & 280 & 10.74 & 160.0 & 39 & A \\
\hline $\mathrm{C} 1-12$ & 24.23 & 24.23 & 334 & 10.77 & 159.0 & 27 & A \\
\hline $\mathrm{C} 1-13$ & 24.11 & 24.11 & 388 & 10.80 & 158.0 & 26 & A \\
\hline $\mathrm{C} 1-14$ & 23.99 & 23.99 & 441 & 10.83 & 157.0 & 21 & A \\
\hline C1-15 & 23.87 & 23.87 & 493 & 10.85 & 156.0 & 17 & A \\
\hline C1-16 & 23.63 & 23.63 & 597 & 10.88 & 154.1 & 14 & A \\
\hline $\mathrm{C} 2-0$ & 35.00 & 35.00 & 0 & 7.08 & 248.1 & 15 & $\mathrm{C}$ \\
\hline C2-1 & 34.96 & 34.96 & 12 & 9.98 & 247.9 & 17 & - \\
\hline $\mathrm{C} 2-2$ & 34.93 & 34.93 & 23 & 10.16 & 247.5 & 29 & $\mathrm{C}$ \\
\hline $\mathrm{C} 2-3$ & 34.85 & 34.85 & 46 & 10.33 & 246.9 & 60 & - \\
\hline $\mathrm{C} 2-4$ & 34.82 & 34.82 & 57 & 10.37 & 245.5 & 88 & - \\
\hline $\mathrm{C} 2-5$ & 34.71 & 34.71 & 91 & 10.48 & 245.6 & 90 & - \\
\hline C2-6 & 34.67 & 34.67 & 102 & 10.50 & 245.3 & 72 & C \\
\hline $\mathrm{C} 2-7$ & 34.63 & 34.63 & 114 & 10.53 & 245.0 & 47 & $\mathrm{C}$ \\
\hline C2-8 & 34.56 & 34.56 & 136 & 10.57 & 244.4 & 37 & - \\
\hline C2-9 & 34.45 & 34.45 & 170 & 10.62 & 243.5 & 35 & - \\
\hline C2-10 & 34.10 & 34.10 & 280 & 10.72 & 240.5 & 2 & $\mathrm{H}+\mathrm{C}$ \\
\hline C2-11 & 33.93 & 33.93 & 334 & 10.76 & 239.0 & 1 & $\mathrm{H}$ \\
\hline C2-12 & 33.75 & 33.75 & 388 & 10.79 & 237.5 & 1 & $\mathrm{H}$ \\
\hline C2-13 & 33.58 & 33.58 & 441 & 10.81 & 236.1 & $<1$ & $\mathrm{H}$ \\
\hline $\mathrm{C} 2-14$ & 33.41 & 33.41 & 493 & 10.83 & 234.7 & $<1$ & $\mathrm{H}$ \\
\hline C3-0 & 50.00 & 50.00 & 0 & 7.09 & 381.2 & 9 & $\mathrm{C}$ \\
\hline C3-1 & 49.95 & 49.95 & 12 & 9.95 & 380.7 & 11 & $\mathrm{C}$ \\
\hline C3-2 & 49.89 & 49.89 & 23 & 10.15 & 380.1 & 11 & $\mathrm{C}$ \\
\hline C3-3 & 49.79 & 49.79 & 46 & 10.30 & 379.4 & 14 & $\mathrm{C}+\mathrm{H}$ \\
\hline C3-4 & 49.74 & 49.74 & 57 & 10.35 & 378.8 & 18 & $\mathrm{C}$ \\
\hline C3-5 & 49.63 & 49.63 & 80 & 10.44 & 378.0 & 17 & $\mathrm{H}$ \\
\hline C3-6 & 49.58 & 49.58 & 91 & 10.46 & 377.5 & 29 & $\mathrm{H}$ \\
\hline C3-7 & 49.53 & 49.53 & 102 & 10.49 & 376.9 & 32 & - \\
\hline C3-8 & 49.48 & 49.48 & 114 & 10.51 & 376.4 & 37 & - \\
\hline C3-9 & 49.22 & 49.22 & 170 & 10.95 & 374.3 & 31 & $\mathrm{H}$ \\
\hline C3-10 & 48.72 & 48.72 & 280 & 11.39 & 369.5 & $<1$ & - \\
\hline C3-11 & 48.47 & 48.47 & 334 & 11.13 & 367.1 & $<1$ & $\mathrm{C}$ \\
\hline C3-12 & 48.22 & 48.22 & 388 & 11.13 & 365.0 & $<1$ & $\mathrm{H}$ \\
\hline C3-13 & 47.98 & 47.98 & 441 & 11.13 & 362.7 & $<1$ & $\mathrm{H}$ \\
\hline C3-14 & 47.73 & 47.73 & 493 & 11.13 & 360.7 & $<1$ & $\mathrm{H}$ \\
\hline C4-0 & 75.00 & 75.00 & 0 & 7.10 & 623.0 & 4 & C \\
\hline C4-1 & 74.92 & 74.92 & 12 & 9.94 & 622.0 & 3 & $\mathrm{C}$ \\
\hline $\mathrm{C} 4-2$ & 74.84 & 74.84 & 23 & 10.12 & 621.6 & 3 & $\mathrm{C}$ \\
\hline C4-3 & 74.68 & 74.68 & 46 & 10.29 & 620.1 & 4 & $\mathrm{C}$ \\
\hline C4-4 & 74.61 & 74.61 & 57 & 10.33 & 619.0 & 5 & $\mathrm{C}$ \\
\hline C4-5 & 74.45 & 74.45 & 80 & 10.41 & 617.1 & 6 & - \\
\hline C4-6 & 74.37 & 74.37 & 91 & 10.44 & 616.1 & 7 & - \\
\hline C4-7 & 74.29 & 74.29 & 102 & 10.47 & 615.6 & 6 & - \\
\hline C4-8 & 74.22 & 74.22 & 114 & 10.49 & 614.6 & 7 & $\mathrm{C}+\mathrm{H}$ \\
\hline C4-9 & 74.06 & 74.06 & 136 & 10.53 & 613.1 & 10 & $\mathrm{H}+\mathrm{C}$ \\
\hline
\end{tabular}


Table 1 (continued)

\begin{tabular}{|c|c|c|c|c|c|c|c|}
\hline Experiment number & $\mathrm{Na}_{2} \mathrm{SO}_{4}(\mathrm{mmol} / \mathrm{l})$ & $\mathrm{SrCl}_{2}(\mathrm{mmol} / \mathrm{l})$ & {$[\mathrm{Si}]_{\text {tot }}(\mathrm{ppm})$} & $\mathrm{pH}$ & Supersaturation $\beta_{\text {celestite }}$ & Time (s) & Phase \\
\hline C4-10 & 73.83 & 73.83 & 170 & 10.58 & 611.2 & 4 & - \\
\hline C4-11 & 73.07 & 73.07 & 280 & 10.68 & 603.3 & $<1$ & A? \\
\hline $\mathrm{C} 4-12$ & 72.70 & 72.70 & 334 & 10.72 & 599.5 & $<1$ & $\mathrm{~A} ?$ \\
\hline C4-13 & 72.33 & 72.33 & 388 & 10.75 & 595.6 & $<1$ & $\mathrm{~A}+\mathrm{H} ?$ \\
\hline C4-14 & 71.96 & 71.96 & 441 & 10.77 & 592.3 & $<1$ & $\mathrm{~A}+\mathrm{H} ?$ \\
\hline C4-15 & 71.60 & 71.60 & 493 & 10.80 & 588.3 & $<1$ & $\mathrm{~A}+\mathrm{H} ?$ \\
\hline C4-16 & 70.89 & 70.89 & 597 & 10.83 & 581.6 & $<1$ & $\mathrm{~A}+\mathrm{H} ?$ \\
\hline
\end{tabular}

Table 2

AFM growth experiments: concentration of the reactants, total silicon concentration, calculated $\mathrm{pH}$ of the solutions, ionic activities, supersaturation of the solutions with respect to celestite, and velocities of the $\langle 120\rangle$ steps.

\begin{tabular}{|c|c|c|c|c|c|c|c|c|}
\hline $\begin{array}{l}\text { Experiment } \\
\text { number }\end{array}$ & $\begin{array}{l}\mathrm{Na}_{2} \mathrm{SO}_{4} \\
(\mathrm{mmol} / \mathrm{l})\end{array}$ & $\begin{array}{l}\mathrm{SrCl}_{2} \\
(\mathrm{mmol} / \mathrm{l})\end{array}$ & $\begin{array}{l}{[\mathrm{Si}]_{\mathrm{tot}}} \\
(\mathrm{ppm})\end{array}$ & $a\left(\mathrm{SO}_{4}^{2-}\right)$ & $a\left(\mathrm{Sr}^{2+}\right)$ & $\mathrm{pH}$ & $\begin{array}{l}\text { Supersaturation } \\
\beta_{\text {celestite }}\end{array}$ & $\begin{array}{l}<120> \\
(\mathrm{nm} / \mathrm{s})\end{array}$ \\
\hline G1 & 1.40 & 1.40 & 0 & $8.64 \times 10^{-4}$ & $8.77 \times 10^{-4}$ & 7.14 & 3.23 & 0.70 \\
\hline G2 & 1.40 & 1.40 & 2.3 & $8.61 \times 10^{-4}$ & $8.74 \times 10^{-4}$ & 10.01 & 3.23 & 1.30 \\
\hline G3 & 1.40 & 1.40 & 4.6 & $8.58 \times 10^{-4}$ & $8.72 \times 10^{-4}$ & 10.27 & 3.23 & 1.43 \\
\hline G4 & 1.40 & 1.40 & 9.2 & $8.53 \times 10^{-4}$ & $8.67 \times 10^{-4}$ & 10.53 & 3.16 & 1.88 \\
\hline G5 & 1.40 & 1.40 & 11.5 & $8.50 \times 10^{-4}$ & $8.65 \times 10^{-4}$ & 10.62 & 3.16 & 1.83 \\
\hline G6 & 1.40 & 1.40 & 13.8 & $8.48 \times 10^{-4}$ & $8.62 \times 10^{-4}$ & 10.69 & 3.16 & 3.43 \\
\hline G7 & 1.40 & 1.40 & 16.1 & $8.46 \times 10^{-4}$ & $8.60 \times 10^{-4}$ & 10.75 & 3.10 & 4.16 \\
\hline G8 & 1.40 & 1.40 & 18.4 & $8.43 \times 10^{-4}$ & $8.58 \times 10^{-4}$ & 10.80 & 3.10 & 4.74 \\
\hline G9 & 1.40 & 1.40 & 20.7 & $8.41 \times 10^{-4}$ & $8.56 \times 10^{-4}$ & 10.85 & 3.10 & 4.41 \\
\hline G10 & 1.40 & 1.40 & 23.0 & $8.38 \times 10^{-4}$ & $8.53 \times 10^{-4}$ & 10.89 & 3.10 & 4.49 \\
\hline G11 & 1.40 & 1.40 & 27.6 & $8.33 \times 10^{-4}$ & $8.49 \times 10^{-4}$ & 10.97 & 3.02 & 4.72 \\
\hline
\end{tabular}

\subsection{Atomic force microscopy (AFM) observations}

In situ growth experiments on the celestite (001) face were conducted at room temperature using an AFM equipped with an approximately $14 \times 14 \mu^{2}$ (E) scanner and a fluid cell (Multimode Veeco Instruments). Celestite samples were optically clear single crystals from Madagascar. Crystals were freshly cleaved on the (001) face prior to each growth experiment and placed in the fluid cell of the AFM. At the start of each experiment, deionised water was passed over the celestite (001) surface to adjust the AFM parameters, which led to the slight dissolution of celestite surfaces by both the retreat of cleavage steps and the nucleation and spread of etch pits. Then, growth on celestite surfaces was promoted by injecting into the AFM fluid cell aqueous solutions with an almost constant supersaturation with respect to celestite and with increasing concentrations of dissolved silicon. A number of additional experiments were conducted at constant concentrations of dissolved silicon and increasing supersaturation with respect to celestite. To keep the composition in the fluid cell constant, all the experiments were conducted by injecting fresh solution at intervals of about 1 min between each AFM scan. Growth solutions were prepared from reagent grade $\mathrm{SrCl}_{2}, \mathrm{Na}_{2} \mathrm{CO}_{3}$ and $\mathrm{Na}_{2} \mathrm{SiO}_{3}$ solutions and deionised water (MilliQ Millipore; resistivity $18 \mathrm{M} \Omega \mathrm{cm}$ ). As in the case of the precipitation experiments, ionic activities were calculated with the PHREEQC computer code and the PHREEQC.DAT database (Parkhurst and Appelo, 1999). The supersaturation with respect to celestite was also calculated using Eq. (1). Tables 2 and 3 show the concentrations of $\mathrm{SrCl}_{2}$ and $\mathrm{Na}_{2} \mathrm{SO}_{4}$, the ionic activities, the total silicon content and the supersaturation with respect to celestite of the solutions used.

During the growth on celestite (001) faces, AFM images were recorded in constant force mode while displaying cantilever height, deflection and friction signals. Silicon nitride tips (Veeco NP and NP-S) with a nominal force constant of $k=0.06-0.58 \mathrm{~N} / \mathrm{m}$ were used. AFM images were obtained at scan rates that typically varied from approximately $5-10.2 \mathrm{~Hz}$, with 256 lines per scan. For each concentration of total dissolved silicon in the aqueous solution, growth velocities of the celestite $<120>$ steps were measured from sequences of AFM deflection and friction images. Friction images were useful to conduct these velocity measurements because they allowed us to recognise the newly grown areas. To both check the reproducibility of the observations and minimise random errors, experiments were repeated several times, and step velocities were measured for different steps for each experimental run.

A number of additional high-resolution AFM images of celestite (001) surfaces previously grown in the presence of dissolved silicon were also recorded. These images were collected at scan rates that varied from approximately 20 to $60 \mathrm{~Hz}$, with 512 lines per scan. Scan areas varied from $5 \times 5 \mathrm{~nm}^{2}$ to $50 \times 50 \mathrm{~nm}^{2}$. High-resolution images were taken using the same AFM scanner and tips as those used in the growth experiments. Both height and friction signals were recorded. AFM images were analysed using the software provided by nanoscope (5.30r3sr3) and nanotec (WSxM. 2.1) (Horcas et al., 2007). 
Table 3

AFM recovery experiments: concentration of the reactants, total silicon concentration, ionic activities, calculated $\mathrm{pH}$ values and supersaturation of the solutions with respect to celestite. Recovery experiments were conducted on a previously-grown self-inhibiting celestite monolayer (experiment number R0). (See explanation in the text).

\begin{tabular}{|c|c|c|c|c|c|c|c|c|}
\hline $\begin{array}{l}\text { Experiment } \\
\text { number }\end{array}$ & $\begin{array}{l}\mathrm{Na}_{2} \mathrm{SO}_{4} \\
(\mathrm{mmol} / \mathrm{l})\end{array}$ & $\begin{array}{l}\mathrm{SrCl}_{2} \\
(\mathrm{mmol} / \mathrm{l})\end{array}$ & $\begin{array}{l}{[\mathrm{Si}]_{\text {tot }}} \\
(\mathrm{ppm})\end{array}$ & $a\left(\mathrm{SO}_{4}^{2-}\right)$ & $a\left(\mathrm{Sr}^{2+}\right)$ & $\mathrm{pH}$ & $\begin{array}{l}\text { Supersaturation } \\
\beta_{\text {celestite }}\end{array}$ & Observations \\
\hline R0 & 1.40 & 1.40 & 23.0 & $8.4 \times 10^{-4}$ & $8.5 \times 10^{-4}$ & 10.89 & 3.1 & $\begin{array}{l}\text { Growth of a } \\
\text { self-inhibiting } \\
\text { monolayer }\end{array}$ \\
\hline $\mathrm{R} 1$ & 2.25 & 2.25 & 23.0 & $1.2 \times 10^{-3}$ & $1.2 \times 10^{-3}$ & 8.57 & 6.5 & No growth \\
\hline $\mathrm{R} 2$ & 2.60 & 2.60 & 23.0 & $1.4 \times 10^{-3}$ & $1.4 \times 10^{-3}$ & 8.56 & 7.9 & No growth \\
\hline $\mathrm{R} 4$ & 3.30 & 3.30 & 23.0 & $1.6 \times 10^{-3}$ & $1.6 \times 10^{-3}$ & 8.56 & 11.2 & No growth \\
\hline R5 & 3.65 & 3.65 & 23.0 & $1.7 \times 10^{-3}$ & $1.8 \times 10^{-3}$ & 8.55 & 13.2 & No growth \\
\hline R6 & 4.00 & 4.00 & 23.0 & $1.8 \times 10^{-3}$ & $1.9 \times 10^{-3}$ & 8.55 & 15.1 & 2D-nucleation \\
\hline R7 & 4.40 & 4.40 & 23.0 & $1.9 \times 10^{-3}$ & $2.0 \times 10^{-3}$ & 8.55 & 16.9 & 2D-nucleation \\
\hline R8 & 4.80 & 4.80 & 23.0 & $2.1 \times 10^{-3}$ & $2.7 \times 10^{-3}$ & 8.55 & 19.5 & 2D-nucleation \\
\hline
\end{tabular}

\section{RESULTS AND DISCUSSION}

\subsection{Precipitation of strontium sulphates from Si-bearing solutions}

Precipitation experiments show that the presence of dissolved silicon leads to significant changes in the nucleation kinetics within the $\mathrm{SrCl}_{2}-\mathrm{Na}_{2} \mathrm{SO}_{4}-\mathrm{H}_{2} \mathrm{O}$ system. Fig. 1 shows the experimental induction times for homogeneous nucleation versus the initial total silicon concentration, [Si]tot, for the four series of solutions used. At low concentrations of dissolved silicon, an increase in the induction times for homogeneous nucleation occurs in the four precipitation series. Such an increase is more pronounced for solutions with lower supersaturation with respect to celestite. In contrast, the increase in the dissolved silicon in the solutions results in a rapid reduction in the induction times at high $[\mathrm{Si}]_{\text {tot. }}$ This bimodal inhibitor/promotor effect of the dissolved silicon on the homogeneous nucleation kinetics is also accompanied by changes in the nature of the precipitates. X-ray diffraction allowed us to identify three different phases in the precipitates: celestite $\left(\mathrm{SrSO}_{4}\right)$, strontium sulphate hemihydrate $\left(\mathrm{SrSO}_{4} \cdot 0.5 \mathrm{H}_{2} \mathrm{O}\right)$ and an amorphous phase (see Fig. 2). The diffractograms of the amorphous phase frequently show a broad peak in the range of $2 \theta$ from $15^{\circ}$ to $40^{\circ}$ with an intensity maxima around $2 \theta=25^{\circ}$, i.e. a peak characteristic of amorphous silica (Martinez et al., 2006; Zhang et al., 2008; Musić et al., 2011). This suggests that the amorphous phase has a disordered silicate structure, formed during the polymerisation of sodium silicate in the aqueous solutions with high $[\mathrm{Si}]_{\text {tot }}$. EDX analyses of the amorphous phase provided total silicon concentrations of about 40 weight $\%$ and concentrations of strontium of about 4 weight $\%$. These analyses are consistent with the formation of a silicate precipitate. Such a formation is further supported by the recent finding of the precipitation of a barium silicate phase from barium sulphate solutions containing dissolved silicon (Jones et al., 2012).

As shown in Fig. 1, at low $[\mathrm{Si}]_{\text {tot }}$, the precipitation of celestite is always observed, whereas the precipitation of this mineral phase is inhibited and the formation of $\mathrm{SrSO}_{4} \cdot 0.5 \mathrm{H}_{2} \mathrm{O}$ and the amorphous phase becomes

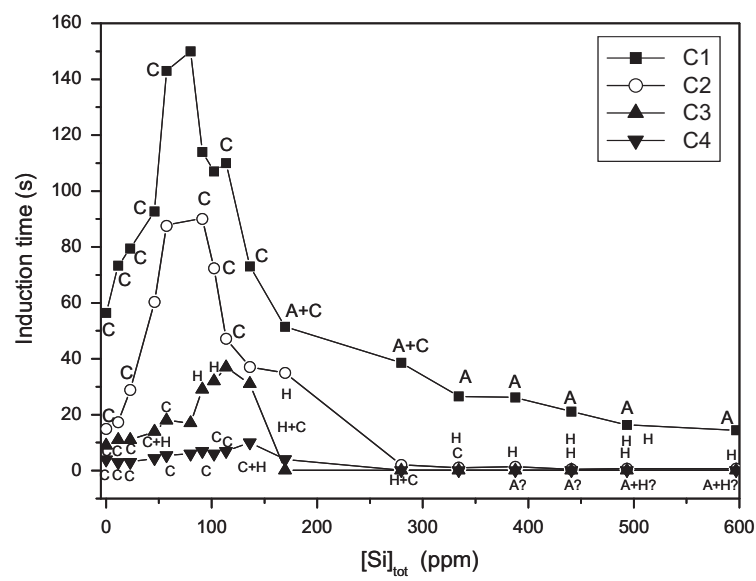

Fig. 1. Experimental induction times for homogeneous nucleation versus the concentration of initial total dissolved silicon in the $\mathrm{SrCl}_{2}-\mathrm{Na}_{2} \mathrm{SO}_{4}-\mathrm{Na}_{2} \mathrm{SiO}_{3}-\mathrm{H}_{2} \mathrm{O}$ system. The letters on the data points indicate the phases identified by X-ray diffraction: $\mathrm{C}, \mathrm{SrSO}_{4}$, celestite; $\mathrm{H}, \mathrm{SrSO}_{4} \cdot 0.5 \mathrm{H}_{2} \mathrm{O}$, and $\mathrm{A}$, amorphous (question marks indicate unreliable phase identification). Experimental conditions are given in Table 1 .

predominant for $[\mathrm{Si}]_{\text {tot }}$ above $100-150 \mathrm{ppm}$ (depending on the supersaturation with respect to celestite of the aqueous solution). The inhibiting effect of the dissolved silicon on celestite precipitation at low $[\mathrm{Si}]_{\text {tot }}$ (i.e. when celestite is the only phase formed) can be further evaluated with the analysis of the induction times shown in Fig. 1 and listed in Table 4 (column 4). According to the classical nucleation theory, induction times can be related to supersaturation by means of the following equation (Wojciechowski and Kibalczyc, 1986; Mullin, 2001 and references therein):

$\ln \left(t_{\text {ind }}\right)=A+B \frac{\alpha^{3} \Omega^{2}}{k^{3} T^{3}}(\ln \beta)^{-2}$

where $A$ is a constant, $B$ is a shape factor equal to $16 \pi / 3$ for a spherical nucleus, $\alpha$ is the interfacial free energy, $\Omega$ is the molecular volume of the growth unit, $k$ is the Boltzmann constant $\left(1.38 \times 10^{-23} \mathrm{~J} / \mathrm{K}\right), T$ is the absolute temperature and $\beta$ is the supersaturation (which for the case of celestite 
is expressed by Eq. (1)). Therefore, crystal-solution interfacial free energies can be estimated from experimental plots in which a linear dependence of $\ln \left(t_{\text {ind }}\right)$ on $(\ln \beta)^{-2}$ is found. From Eq. (2), the slope of such a linear dependence is:

$m=\frac{16 \pi \alpha^{3} \Omega^{2}}{3 k^{3} T^{3}}$

Consequently, the interfacial free energy is given by:

$\alpha=k T\left(\sqrt[3]{\frac{3 m}{16 \pi \Omega^{2}}}\right)$

The interfacial free energy is a fundamental parameter characterising crystal-solution interfaces that can be used to quantify the effect of inhibiting agents, e.g. organic molecules and ions (e.g., Fernández-Díaz et al., 1990; Manoli and Dalas, 2001). In general, the inhibition of nucleation results from an increase in the interfacial crystal-solution free energy due to the modification of the crystal surface properties by the inhibitors. Such a modification can occur by adsorption of the inhibitors onto the crystal surfaces or by their incorporation into the crystal structure. Fig. 3a shows a clear linear dependence of $\ln \left(t_{\text {ind }}\right)$ on $\left(\ln \beta_{\text {celestite }}\right)^{-2}$ in the precipitation experiments where only the formation of celestite was detected. By introducing the slopes of the fitted lines to the experimental data into Eq. (4), the interfacial free energies between celestite and aqueous solutions with increasing concentrations of dissolved silicon were calculated (see Table 4 and Fig. 3b). In the absence of dissolved silicon, the interfacial free energy for celestite determined from our data is $50 \pm 1.87 \mathrm{~mJ} / \mathrm{m}^{2}$. This value is lower but comparable to previously reported interfacial free energies for celestite obtained from precipitation experiments $\left(72-87 \mathrm{~mJ} / \mathrm{m}^{2}\right)$ and theoretical calculations for the (001) face $\left(67 \mathrm{~mJ} / \mathrm{m}^{2}\right)$ (Bennema and Söhnel, 1990; Wu and Nancollas, 1998 and references therein; Pina et al., 2004). As can be seen in Fig. 3b, the celestite interfacial free energy increases to approximately $54 \mathrm{~mJ} / \mathrm{m}^{2}$ when precipitation occurs in the presence of dissolved silicon, which is consistent with a moderate inhibiting effect of dissolved silicon on the nucleation of celestite. However, the increase in interfacial free energy occurs for $[\mathrm{Si}]_{\text {tot }}<15 \mathrm{ppm}$ and remains almost constant for any further increase in the concentration of dissolved silicon. Such a trend in the interfacial free energy cannot explain the further increase in induction times observed for $[\mathrm{Si}]_{\text {tot }}$ between 15 and $56 \mathrm{ppm}$, which might be affected by a decrease in ionic mobility at high concentrations of dissolved silicon species. In any case, at the initial $\mathrm{pHs}$ of the precipitating solutions (ranging from 9.4 to 11.4 ), the $\mathrm{H}_{3} \mathrm{SiO}_{4}^{-}, \mathrm{H}_{4} \mathrm{SiO}_{4}$ and, to a
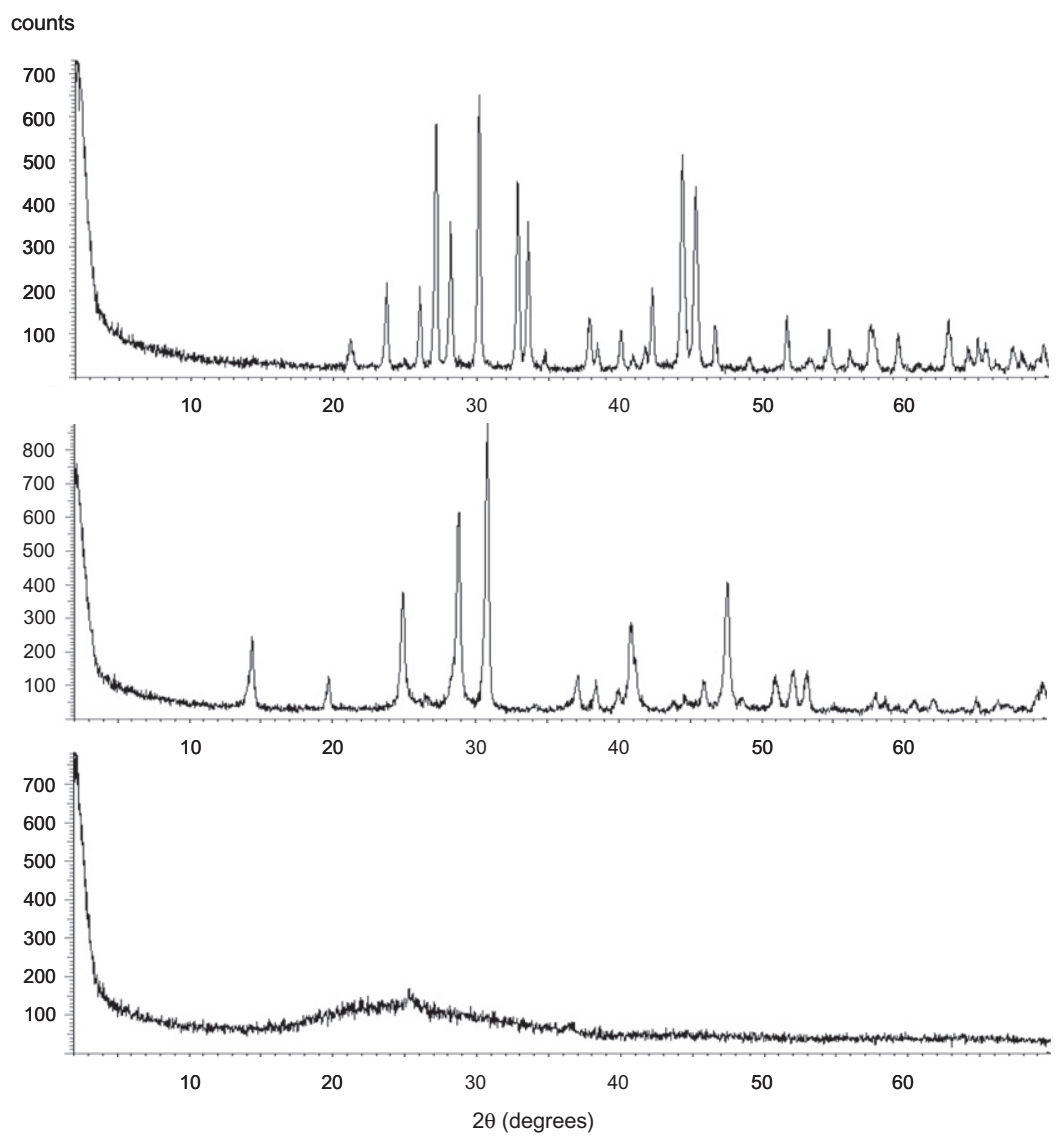

Fig. 2. Typical diffractograms of the precipitates obtained in the nucleation experiments. (a) $\mathrm{SrSO}_{4}$, celestite; (b) $\mathrm{SrSO}_{4} \cdot 0.5 \mathrm{H}_{2} \mathrm{O}$, and (c) amorphous phase. 
Table 4

Celestite interfacial free energy: supersaturation with respect to celestite, total silicon concentration, induction time, and calculated interfacial free energy. (See explanation in the text).

\begin{tabular}{llrrl}
\hline $\begin{array}{l}\text { Experiment } \\
\text { Number }\end{array}$ & $\begin{array}{l}\text { Supersaturation } \\
\beta_{\text {celestite }}\end{array}$ & $\begin{array}{l}{[\mathrm{Si}]_{\mathrm{tot}}} \\
\mathrm{ppm}\end{array}$ & \multicolumn{1}{l}{$\begin{array}{l}\text { Induction time } \\
\mathrm{S}\end{array}$} & $\begin{array}{l}\alpha \\
\mathrm{mJ} / \mathrm{m}^{2}\end{array}$ \\
\hline $\mathrm{C} 1-0$ & 165.11 & 0 & 56 & $50.2 \pm 1.9$ \\
$\mathrm{C} 2-0$ & 248.14 & 0 & 15 & \\
$\mathrm{C} 3-0$ & 381.25 & 0 & 9 & \\
$\mathrm{C} 4-0$ & 623.04 & 0 & 4 & \\
$\mathrm{C} 1-1$ & 164.90 & 12 & 73 & $53.3 \pm 3.0$ \\
$\mathrm{C} 2-1$ & 247.82 & 12 & 17 & \\
$\mathrm{C} 3-1$ & 380.66 & 12 & 11 & \\
$\mathrm{C} 4-1$ & 621.99 & 12 & 3 & $54.7 \pm 2.8$ \\
$\mathrm{C} 1-2$ & 164.69 & 23 & 79 & \\
$\mathrm{C} 2-2$ & 247.50 & 23 & 29 & \\
$\mathrm{C} 3-2$ & 380.12 & 23 & 11 & \\
$\mathrm{C} 4-2$ & 621.55 & 23 & 3 & \\
$\mathrm{C} 1-3$ & 164.27 & 46 & 93 & \\
$\mathrm{C} 2-3$ & 246.89 & 46 & 60 & \\
$\mathrm{C} 4-3$ & 620.07 & 46 & 4 & \\
$\mathrm{C} 1-4$ & 164.05 & 57 & 143 & \\
$\mathrm{C} 2-4$ & 245.48 & 57 & 88 & \\
$\mathrm{C} 3-4$ & 378.78 & 57 & 18 & \\
$\mathrm{C} 4-4$ & 619.03 & 57 & 5 & \\
\hline
\end{tabular}

lesser extent, the $\mathrm{H}_{2} \mathrm{SiO}_{4}^{2-}$ monomeric silicic species can be considered the main silicon species responsible for the inhibition of the nucleation of celestite.

From inspection of Fig. 1, it is clear that nucleation kinetics and phase formation in the $\mathrm{SrCl}_{2}-\mathrm{Na}_{2} \mathrm{SO}_{4}-\mathrm{H}_{2} \mathrm{O}$ system cannot be fully explained only in terms of the limited inhibiting effect of dissolved silicon on the nucleation of celestite. Whereas low concentrations of dissolved silicon retard the nucleation of celestite, higher concentrations of silicon lead to a decrease in the induction times for celestite nucleation. At even higher concentrations of dissolved sili- con, this decrease in the induction times is also accompanied by the formation of the hydrated phase $\mathrm{SrSO}_{4} \cdot 0.5 \mathrm{H}_{2} \mathrm{O}$ and the amorphous phase. This complex crystallisation behaviour seems to be related to the polymerisation of dissolved silicon as its concentration increases in the aqueous solutions. According to Iler (1979), at $25^{\circ} \mathrm{C}$, the monomeric soluble form of silica $\mathrm{Si}(\mathrm{OH})_{4}$ polymerises at measurable rates for concentrations higher than about $0.002 \mathrm{~mol} / 1$ (approximately $56 \mathrm{ppm}$ of silicon), i.e. about the silicon concentration above which we observe both a decrease in the induction times for celestite and the precipitation of $\mathrm{SrSO}_{4} \cdot 0.5 \mathrm{H}_{2} \mathrm{O}$. In addition, at $\mathrm{pH}>7$, polymerisation of silica is enhanced Iler (1979). As a consequence of the polymerisation, the concentration of monomeric dissolved silicon species decreases, while the number of large polysilicic acid particles increases within the solution. The surfaces of such particles have negatively charged deprotonated silanol groups, and dissolved cations can easily adsorb onto them. Measurements of relative adsorption of metal ions conducted by Carroll and Freeman (1954) and more recently by Dove and Craven (2005) showed that, after $\mathrm{Ca}^{2+}$ and $\mathrm{Ba}^{2+}, \mathrm{Sr}^{2+}$ is the most strongly adsorbed cation on silica surfaces. Therefore, large polysilicic acid particles would attract $\mathrm{Sr}^{2+}$ from the solution, increasing its concentration on their surfaces and acting as sites that promote heterogeneous nucleation of both celestite and $\mathrm{SrSO}_{4} \cdot 0.5 \mathrm{H}_{2} \mathrm{O}$. As the initial concentration of dissolved silicon increases in the aqueous solutions, the formation of large polysilicic acid particles also increases and their promoting effect on the celestite and $\mathrm{SrSO}_{4} \cdot 0.5 \mathrm{H}_{2} \mathrm{O}$ nucleation overcomes the inhibiting effect of the monomeric dissolved silicon species. In this context, the formation of the hemihydrate strontium sulphate and the amorphous phase at the highest silicon concentrations could be explained by a rapid and extensive polymerisation of $\mathrm{Si}(\mathrm{OH})_{4}$. The polymerisation of monomeric silica species to form polysilicic acid particles is accompanied by a local release of a large number of $\mathrm{OH}^{-}$(Iler, 1979). As a consequence, the surfaces of the
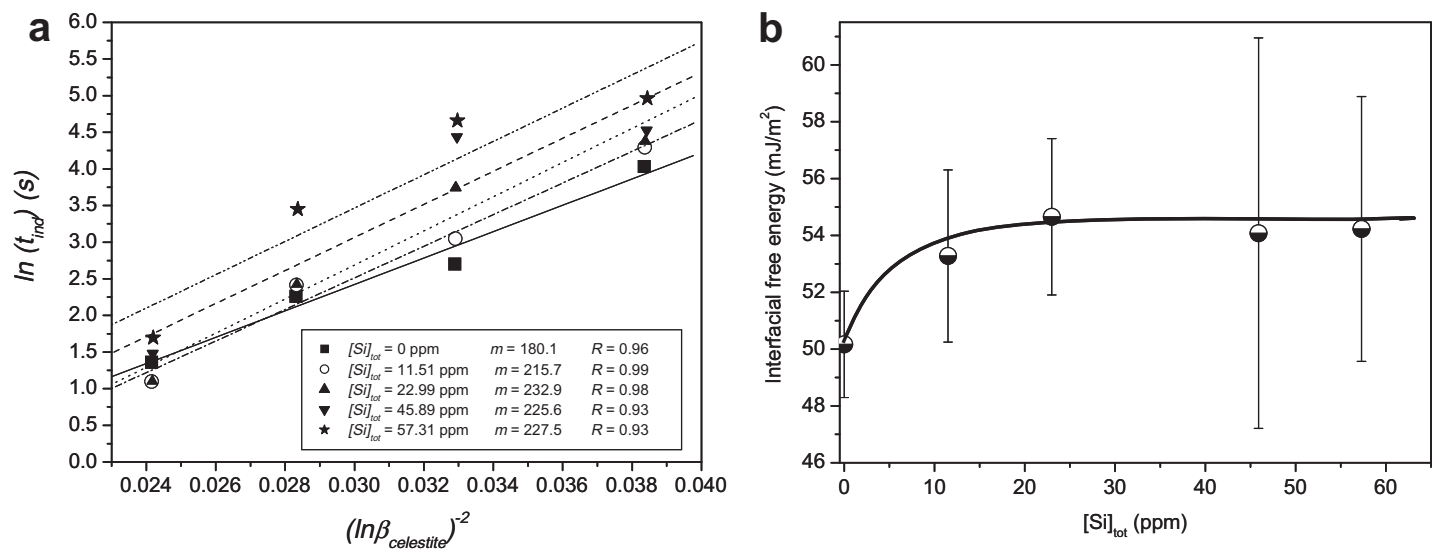

Fig. 3. (a) Logarithm of the induction time versus $\left(\ln \beta_{\text {celestite }}\right)^{-2}$ for solutions with increasing concentrations of dissolved silicon. Linear functions were fitted to the data. The slopes of the fitted lines and corresponding $R^{2}$ values are given in the legend. (b) Interfacial free energies between celestite and aqueous solution as a function of dissolved silicon. These energies were calculated by introducing the slopes obtained in (a) into Eq. (4). (The calculations were conducted for $T=298 \mathrm{~K}$ and for a molecular volume for celestite growth unit $\Omega_{\text {celestite }}=$ $\left.7.7 \times 10^{-2} \mathrm{~nm}^{3}\right)$. The solid line was drawn to guide the eye. 
silica particles, where $\mathrm{Sr}^{2+}$ is also adsorbed, become solvated. This can favour the stabilisation of hydrated strontium sulphate phases.

Recent investigations have shown a bimodal promotor/ inhibitor effect of silicic acids on the growth kinetics of calcite surfaces (Pina et al., 2009). In this case, while large polysilicic acid particles promote two-dimensional nucleation on calcite (104) surfaces, high concentrations of mono- and oligomeric silicic acids have a clear inhibiting effect on calcite growth. A bimodal inhibiting/promoting effect has also been observed in the growth of calcite in the presence of aspartate and aspartate-rich peptide additives (Elhadj et al., 2006). Elhadj and collaborators observed that the inhibition of calcite growth inversely correlates with the length of the polypeptides. All these observations suggest that bimodal promotor/inhibitor effects of additives on crystal growth might be closely related to the ability of such additives to polymerise.

\subsection{The effect of dissolved silicon on the crystal morphology of strontium sulphates}

Dissolved silicon has a strong effect on nucleation behaviour in the $\mathrm{SrCl}_{2}-\mathrm{Na}_{2} \mathrm{SO}_{4}-\mathrm{H}_{2} \mathrm{O}$ system. The presence of dissolved silicon in the precipitating solutions also results in striking changes in crystal habits. Fig. 4 shows SEM images of typical crystal morphologies observed for increasing concentrations of silicon in the aqueous solutions. Celestite crystals formed from solutions without dissolved silicon exhibit characteristic rounded lens-shaped habits (see Fig. 4a). Although goniometric measurements were not conducted, inspection of the SEM images indicate that celestite crystals are occasionally defined by $\{210\}$ and $\{011\}$ forms and to a lesser extent by the (001) face. In the presence of dissolved silicon, celestite sizes and morphologies are clearly modified: crystals become larger, and their surfaces become rougher. In addition, split growth is observed. From inspection of crystal morphologies, the split growth seems to be mainly related to the interaction of silicic species with the celestite (001) surfaces, which inhibits their growth and promotes a progressive misorientation of the (001) planes as growth proceeds. As a result, celestite crystals show rounded peanut-like habits with a radial distribution of (001) planes similar to those frequently observed in some natural crystals, known as desert roses (Fig. 4b). Interestingly, similar morphological effects of dissolved silicon on barite crystals have been recently described by Jones et al., 2012.

Dissolved silicon also modifies the morphology of $\mathrm{SrSO}_{4} \cdot 0.5 \mathrm{H}_{2} \mathrm{O}$ crystals. At moderate silicon concentrations, $\mathrm{SrSO}_{4} \cdot 0.5 \mathrm{H}_{2} \mathrm{O}$ crystallises, forming aggregates of prismatic crystals with a radial distribution (Fig. 4c). Frequently, these crystals appear embedded in a matrix of silica gel, which supports the relationship between the polymerisation of $\mathrm{Si}(\mathrm{OH})_{4}$ and the stabilisation of the $\mathrm{SrSO}_{4} \cdot 0.5 \mathrm{H}_{2} \mathrm{O}$ phase pointed out in the previous section (Fig. 5). As the concentration of silicon increases in the aqueous solutions, individual $\mathrm{SrSO}_{4} \cdot 0.5 \mathrm{H}_{2} \mathrm{O}$ crystals in the radial aggregates become more numerous and thinner. At high silicon concentrations, $\mathrm{SrSO}_{4} \cdot 0.5 \mathrm{H}_{2} \mathrm{O}$ crystals show bundle and sheaf-like morphologies, like those shown in Fig. 4d.
Although no direct correlation between a progressive change in crystal morphologies and silicon content was found, chemical analyses of the crystals indicate that dissolved silicon interacts with celestite and $\mathrm{SrSO}_{4} \cdot 0.5 \mathrm{H}_{2} \mathrm{O}$ crystals during their growth. EDX analyses of both celestite and $\mathrm{SrSO}_{4} \cdot 0.5 \mathrm{H}_{2} \mathrm{O}$ crystal aggregates gave total silicon concentrations up to approximately 2 weight $\%$. Despite this low content of silicon in both celestite and $\mathrm{SrSO}_{4} \cdot 0.5 \mathrm{H}_{2} \mathrm{O}$ aggregates, silicon is able to disrupt the growth process and generate anomalous crystal morphologies.

\subsection{Nanoscale growth of the celestite (001) face in the presence of dissolved silicon}

As previously discussed, dissolved silicon is a strong modifier of celestite crystallisation. Its effect is evidenced by both a modification of induction times for homogeneous nucleation and changes in the morphology of the celestite crystals. However, neither precipitation experiments (and the calculated interfacial free energies) nor the study of the morphological changes provided direct information about the nature of the interaction between the dissolved silicon and the celestite crystals during growth (i.e. adsorption onto the surfaces or incorporation into the celestite crystal structure). To further investigate this aspect, we conducted a series of nanoscale growth experiments on the celestite (001) face. In these experiments, growth was promoted by passing aqueous solutions with constant concentrations of $\mathrm{SrCl}_{2}$ and $\mathrm{Na}_{2} \mathrm{SO}_{4}$ and increasing concentrations of dissolved silicon over celestite surfaces (Table 2). Although supersaturation of the solutions with respect to celestite was close to the transitional supersaturation for two-dimensional nucleation on celestite (001) surfaces (Pina et al., 2000, 2004; Risthaus, 2003), the formation of twodimensional islands was only occasionally observed. Nevertheless, the supersaturation of the solutions with respect to celestite was high enough to easily observe and measure step motion from pre-existent cleavage steps. In Fig. 6, a typical growth sequence from a Si-bearing solution on a celestite (001) face is shown. This sequence is limited to the formation of a first self-inhibiting celestite monolayer, which prevents further layer-by-layer growth. Therefore, it differs from previously reported growth sequences from supersaturated solutions with respect to celestite in which multilayer growth is always observed (e.g. Shindo et al., 1999; Risthaus et al., 2001; Risthaus, 2003). Fig. 6a shows a celestite (001) face after a few minutes of dissolution in deionised water. In these images, the slight dissolution of the cleavage steps and the formation of triangular etch pits with a one half unit cell depth $(\sim 3.4 \AA)$ can be observed. Dissolution of celestite (001) surfaces, performed prior to all growth experiments, was useful to determine the crystallographic orientation of the celestite steps (see arrows in Fig. 6a). Then, deionised water was replaced by the growth solutions in the fluid cell of the AFM. In all cases, after injecting aqueous solutions supersaturated with respect to celestite and bearing dissolved silicon, triangular etch pits were rapidly filled, and cleavage steps started to grow (Fig. 6b-d). Fig. 7 shows the dependence of the velocities of the celestite $<120\rangle$ monosteps (one half unit cell in 

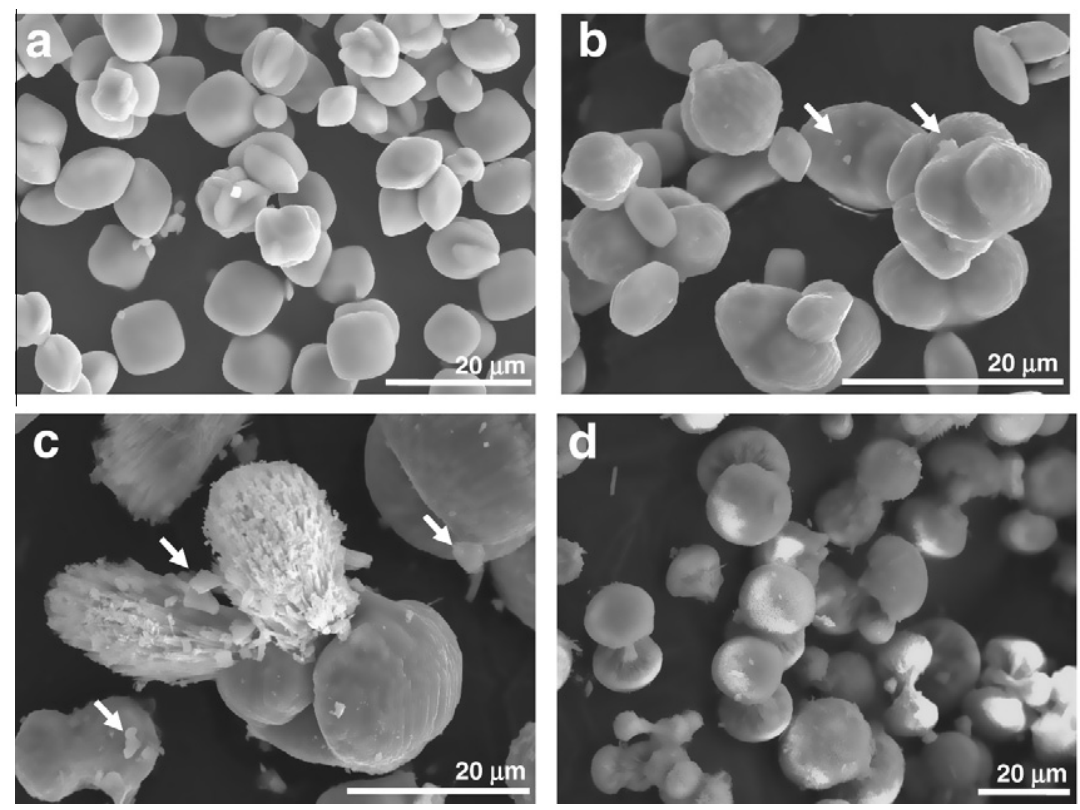

Fig. 4. SEM images of the precipitates formed from aqueous solutions with increasing concentrations of dissolved silicon (solutions $\mathrm{C} 3$ in Table 1). (a) Celestite crystals grown in the absence of dissolved silicon $\left([\mathrm{Si}]_{\text {tot }}=0 \mathrm{ppm}\right.$ ), showing a characteristic lens shape. (b) Celestite crystals grown from a solution with $[\mathrm{Si}]_{\text {tot }}=57 \mathrm{ppm}$. Crystals show clear evidence of split growth, resulting in morphologies resembling natural desert roses. (c) Coexistence of celestite (peanut-like morphologies) and $\mathrm{SrSO}_{4} \cdot 0.5 \mathrm{H}_{2} \mathrm{O}$ (aggregates of acicular crystals) precipitated from a solution with $[\mathrm{Si}]_{\mathrm{tot}}=91 \mathrm{ppm}$. (d) $\mathrm{SrSO}_{4} \cdot 0.5 \mathrm{H}_{2} \mathrm{O}$ with sheaf-like morphologies precipitated from a solution with $[\mathrm{Si}]_{\text {tot }}=170 \mathrm{ppm}$. In (b) and (c), the white arrows indicate the presence of large polysilicic acid particles.

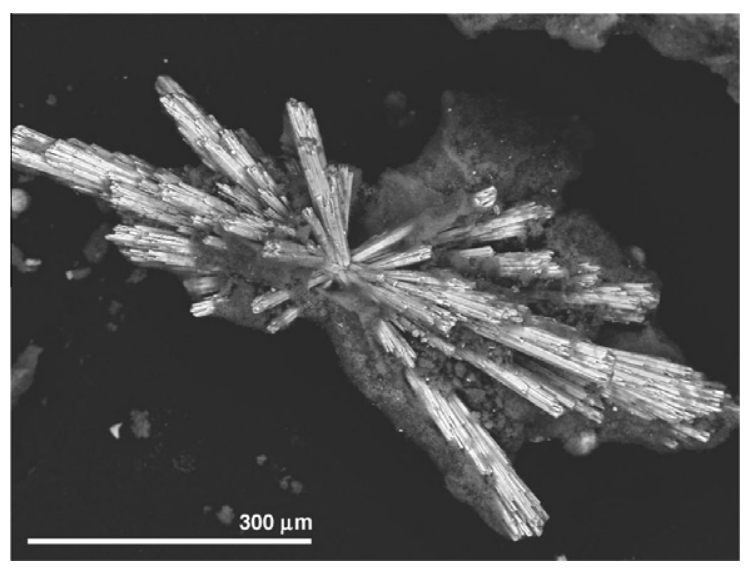

Fig. 5. $\mathrm{SrSO}_{4} \cdot 0.5 \mathrm{H}_{2} \mathrm{O}$ crystal aggregate embedded in a matrix of silica gel.

height) on the concentration of dissolved silicon in the growth solutions. These steps can be considered as proxies of the effect of silicon on step motion on celestite (001) faces because all the steps on this celestite surface behave similarly. As seen in Fig. 7, the increase in the concentration of dissolved silicon leads to a continuous increase in the step growth rates until a rate of about $4.5 \mathrm{~nm} / \mathrm{s}$ is reached. Concentrations of dissolved silicon higher than approximately 15 ppm do not further modify the $<120>$ step rates. This behaviour clearly shows that the dissolved silicon promotes the growth of a self-inhibiting first monolayer on the celestite (001) face, but its effect is limited, i.e. the interac- tion between the silicon and the celestite (001) surfaces is saturated at high $[\mathrm{Si}]_{\text {tot }}$. These data are consistent with the modification of celestite interfacial free energy calculated from the precipitation experiments in Section 3.1, which increases for silicon concentrations lower than about $15 \mathrm{ppm}$ and remaining almost constant above this value (Fig. 3b).

The formation of self-inhibiting first monolayers on mineral surfaces is a common phenomenon that has been observed in numerous experimental systems (Astilleros et al., 2003; Higgins and Hu, 2005; Pina and Rico-García, 2009). Current explanations of such a self-inhibition of growth invoke the existence of compositional and/or structural differences between the newly grown monolayers and the original substrate. These differences result in energy barriers that preclude the advancement of subsequent monolayers from solutions with the same supersaturation levels at which the first monolayers were formed. In Fig. 6, height, deflection and friction AFM images show differences in contrast that demonstrate that the newly grown first monolayer and the original celestite (001) surface are different in composition and/or structure. In the height images, the terraces grown from the pre-existent cleavage steps are brighter. In addition, in the deflection images of the same areas, the edges of the original steps are recognisable after the complete covering of the celestite surface. These observations indicate that the terraces grown in the presence of dissolved silicon are thicker than the original celestite terraces. Measurements conducted on height images yielded typical thickness for the newly grown terraces of about $4.5 \AA$, i.e. approximately $32 \%$ higher than a monolayer of pure 

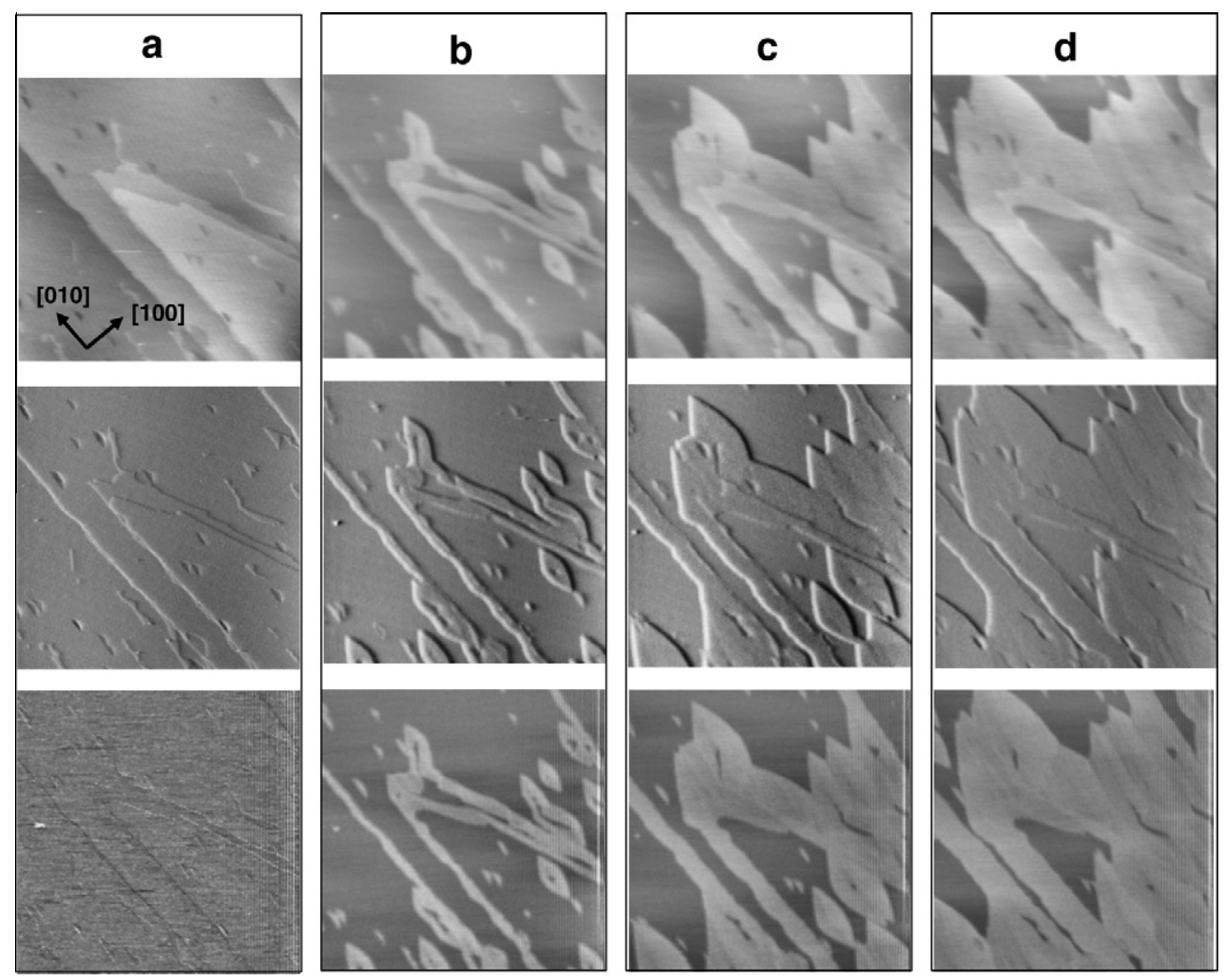

Fig. 6. AFM images of a celestite (001) surface growing from a solution with supersaturation, $\beta_{\text {celestite }}=3.16$, and in the presence of dissolved silicon, $[\mathrm{Si}]_{\mathrm{tot}}=13.8 \mathrm{ppm}$. Three AFM images of the same area $\left(6 \times 6 \mu \mathrm{m}^{2}\right)$ were recorded simultaneously: height images (top row); deflection images (middle row); and friction images (bottom row). The growth sequence is about $38 \mathrm{~s}$. The [100] and [010] crystallographic directions are indicated by arrows in the first height AFM image.

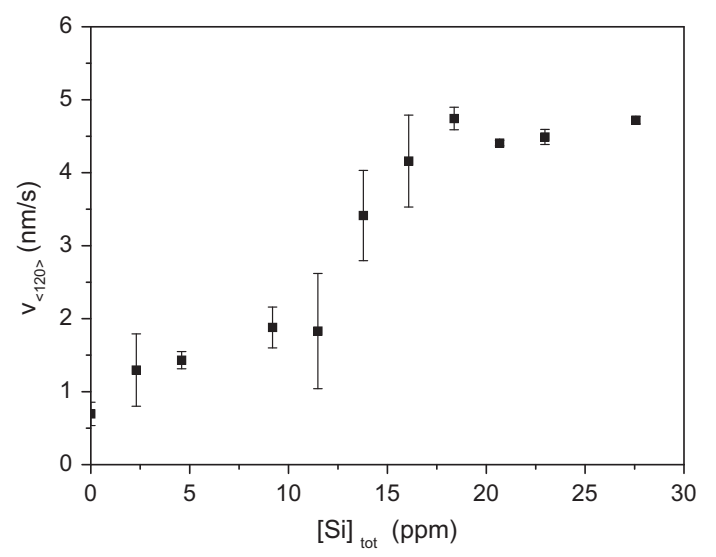

Fig. 7. Growth rates of the $<120>$ steps on the celestite (001) face versus the total concentration of dissolved silicon in the aqueous solution. Growth rates were measured perpendicularly to the direction of the $<120>$ steps.

celestite (3.4 $\AA$ ). Because the $\mathrm{SiO}_{4}$ tetrahedron is larger than the $\mathrm{SO}_{4}$ tetrahedron (the $\mathrm{Si}-\mathrm{O}$ and the $\mathrm{S}-\mathrm{O}$ distances within these tetrahedra are 163 and $149 \mathrm{pm}$, respectively), such an increase in thickness suggests a partial incorporation of $\mathrm{SiO}_{4}$ tetrahedra (or $\mathrm{SiO}_{4}$ groups with different degrees of protonation) into the first monolayer. However, the height measurements of the increased terrace thickness are only indicative and have to be taken with caution. In contact mode, height AFM images are constructed from tip-surface vertical forces. These vertical forces are the result of a number of interactions, such as the repulsion of overlapping electron clouds and electrostatic interaction and the elastic response of the surface (Gan, 2009 and references therein). As a consequence, height measurements conducted between surfaces of different natures (e.g. stiffness) are not entirely reliable. Therefore, it is not possible to directly correlate the increase in the height signal of the first monolayer on the celestite (001) face with the amount of silicon presumably incorporated into the structure.

More reliable evidence of silicon incorporation into the first celestite monolayer is provided by AFM friction images. The sequence of friction images in Fig. 6 shows a marked contrast that allows us to identify the newly grown areas. The comparison of the friction image in Fig. 6a with the corresponding height image demonstrates that frictional contrast is barely affected by vertical forces, i.e. by the nanotopography. Thus, differences in frictional contrast univocally reveal differences in the surface properties. According to previous studies, frictional contrast can be mainly attributed to changes in surface composition or surface strain (Hay et al., 2003; Higgins and Hu, 2005). Furthermore, investigations conducted by Wong et al., 1998 have shown a direct correlation between surface energy 
and friction forces. Therefore, the observed frictional contrast between the newly grown areas and the original celestite (001) substrate is consistent with an increase in the surface energy of the first monolayer. This increase in surface energy may be mainly due to the lattice strain generated by a partial incorporation of the silicon into the celestite structure.

High-resolution AFM images of the newly grown first monolayer also indicate that silicon is incorporated into the celestite structure and that, at least for a low degree of substitution of $\mathrm{SO}_{4}$ by $\mathrm{SiO}_{4}$, the celestite lattice is preserved. Fig. 8 shows a high resolution AFM image of a first celestite (001) monolayer grown in the presence of dissolved silicon. This image has a very similar pattern to those previously reported for the (001) surfaces of the isostructural mineral barite (Bosbach et al., 1998; Bokern et al., 2002) and to those of pure celestite (001) surfaces (not shown in this paper). In addition, periodicities measured along the [100] and [010] directions on 2D-FFT plots, as shown in the inset in Fig. 8, are approximately $0.9 \mathrm{~nm}$ and approximately $0.6 \mathrm{~nm}$, respectively, i.e. in general agreement with the celestite (001) surface unit cell dimensions.

Regardless of the velocity at which the first monolayer grows from solutions containing dissolved silicon, once a celestite (001) surface is covered by such a monolayer no further continuous multilayer growth occurs, i.e. a first Si-bearing celestite (001) monolayer acts as an inhibitor of multilayer growth. Additional AFM experiments (see Table 3 ) showed that the recovery of growth on the (001) face is only observed when the supersaturation with respect to celestite in the solution containing dissolved silicon is greatly increased $\left(\beta_{\text {celestite }}>14.2 \pm 0.95\right)$. However, under

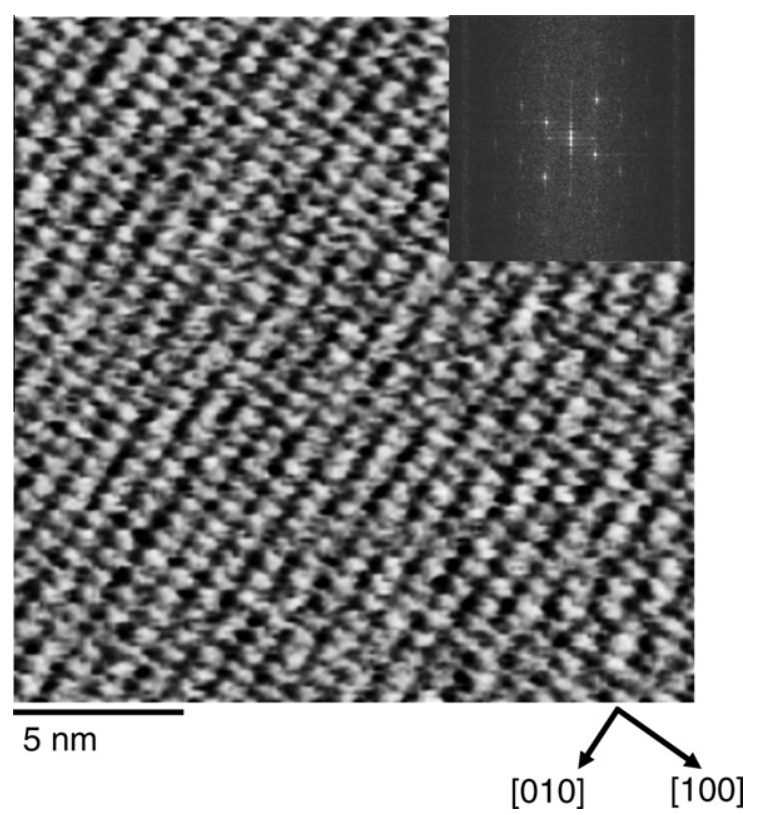

Fig. 8. High-resolution AFM friction image of a first monolayer grown on a celestite (001) face from an aqueous solution with supersaturation, $\beta_{\text {celestite }}=3.1$, and in the presence of dissolved silicon, $[\mathrm{Si}]_{\text {tot }}=20.7 \mathrm{ppm}$. The inset shows the $2 \mathrm{D}-\mathrm{FFT}$ plot of the high-resolution image.

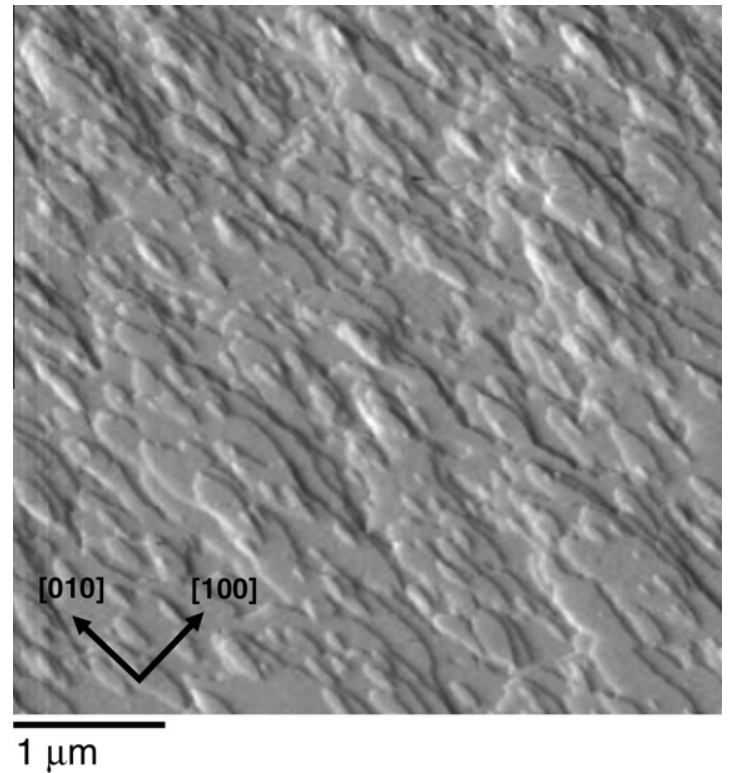

Fig. 9. Recovery of growth on a self-inhibiting monolayer previously grown on a celestite (001) face from a solution containing dissolved silicon (solution R0 in Table 3). Two-dimensional nucleation over the surface occurred from a solution with the same total silicon concentration and with a supersaturation with respect to celestite, $\beta_{\text {celestite }}=19.5$ (solution R8 in Table 3).

such a high-supersaturation condition, growth does not proceed by the advancement of monolayers on the first monolayer; it occurs by the accumulation of numerous two-dimensional nuclei over the celestite (001) face (see Fig. 9). The result is the generation of a surface with a high roughness, which agrees with the SEM observations presented in the previous section (see Fig. 4).

\subsection{The effects of silicon on the crystallisation of celestite}

As discussed in previous sections, the presence of silicon in the crystallisation medium significantly modifies both the nucleation and the growth behaviour of celestite crystals. Precipitation experiments have shown that dissolved silicon with concentrations up to approximately $100 \mathrm{ppm}$ is able to retard celestite homogeneous nucleation. Such a inhibition of celestite nucleation can be partially explained by the observed slight increase in the celestite-solution interfacial free energy. In addition, a reduction in ionic mobility due to the presence of dissolved silicon species in the solutions might also contribute to an increase in the induction times for celestite nucleation. Finally, when total silicon concentration is high enough, polymerisation leads to the formation of large polysilicic acid particles. These particles seem to act as nucleation sites, which promote heterogeneous nucleation of celestite. Therefore, the inhibition of homogeneous nucleation of celestite by dissolved silicon is overcome by the promoting effect of the large silica particles. However, at high dissolved silicon concentrations, a rapid and extensive polymerisation of dissolved silicon promotes the formation of $\mathrm{SrSO}_{4} \cdot 0.5 \mathrm{H}_{2} \mathrm{O}$ and/or an amorphous silicate 
phase. When this occurs, direct celestite nucleation is completely inhibited.

The nucleation behaviour of celestite in the presence of dissolved silicon reveals a strong interaction between celestite surfaces and mono- and polymeric silicic acid species. Such an interaction modifies the properties of the celestite surfaces. This is further evidenced by the striking changes in crystal morphologies when the concentration of dissolved silicon increases. In situ AFM observations of the celestite (001) faces growing from supersaturated solutions and increasing concentrations of dissolved silicon provided information about the interaction between dissolved silicon and celestite surfaces at the nanoscale. Moreover, analysis of AFM data allowed us to infer the incorporation of silicon into the structure of newly-grown celestite (001) monolayers $(\sim 3.4 \AA$ in height). A limited incorporation of silicon into the celestite structure is consistent with semiquantitative EDX analysis of celestite crystals. In addition, for solutions with an almost constant supersaturation with respect to celestite $\left(\beta_{\text {celes- }}\right.$ tite $\approx 3$ ), and concentrations of dissolved silicon ranging from 2.3 to $27.6 \mathrm{ppm}$, the newly-grown monolayers have a selfinhibiting character, i.e. they prevent subsequent multilayer growth. Only when supersaturation is significantly increased recovery of growth on celestite (001) faces occurs. AFM growth recovery experiments have shown that after the formation of a self-inhibiting first celestite monolayer from a solution with a dissolved silicon concentration of $\sim 23 \mathrm{ppm}$, two-dimensional nucleation only occurs when supersaturation with respect to celestite is increased to $\beta_{\text {celestite }} \approx 14$. Recognising that two-dimensional nuclei appear spontaneously on cleaved celestite surfaces for supersaturations above $\beta_{\text {celestite }} \approx 3$ (Pina et al., 2000, 2004; Risthaus, 2003), this value of supersaturation represents an increase in the transitional supersaturation for two-dimensional nucleation growth mechanisms of about $367 \%$. As homogeneous and two-dimensional nucleation are analogous phenomena influenced by common physicochemical parameters (Mullin, 2001), it is reasonable to assume that the incorporation of silicon into the surfaces of subcritical celestite nuclei can affect homogeneous nucleation in a similar way as it does for two-dimensional nucleation on (001) faces.

This paper has shown that the inhibition of celestite formation by dissolved silicon is a complex phenomenon controlled by numerous factors that include: (i) the modification of celestite-solutions interfacial free energies, (ii) the limited introduction of silicon into the celestite structure and the formation self-inhibiting monolayers, (iii) the polymerisation behaviour of silicic acids and (iv) the stabilisation of other phases such as $\mathrm{SrSO}_{4} \cdot 0.5 \mathrm{H}_{2} \mathrm{O}$ and amorphous precipitates. Since celestite is one of the endmembers of the continuous $\mathrm{Ba}_{x} \mathrm{Sr}_{1-x} \mathrm{SO}_{4}$ solid solution, it is expected that similar factors are likely to affect the formation of barite and $\mathrm{Sr}$-barites.

The results discussed here suggest that a significant effect of silicon on the crystallisation of strontium (and barium) sulphates can only occur in silica-rich environments such as: (i) porous of deep seafloor siliceous sediments (Siever, 1957), (ii) proximities of hydrothermal systems at midocean ridges (where concentrations of dissolved silicon can increase up to $644 \mathrm{ppm}$ (Von Damm, 1995; Andrews et al., 2004)) and (iii) microenvironments generated by marine microorganisms (e.g. the interior of siliceous shells of radiolarians from the family Collosphaeridae that contain $\mathrm{SrSO}_{4}$ granules (Hollande and Martoja, 1974)). Furthermore, high concentrations of silicon in marine precipitation media can determine the formation of precursor phases such as hydrated or amorphous phases. Thus, the crystallisation behaviour of strontium and barium sulphates in silica-rich natural environments might influence the geochemistry of $\mathrm{Ba}, \mathrm{Sr}$ and $\mathrm{Si}$. However, further studies are needed to completely elucidate and quantify the effects of silicon on the crystallisation of celestite and Sr-bearing barites in both laboratory and nature.

\section{ACKNOWLEDGEMENTS}

The authors thank the UCM-Comunidad de Madrid (Grant No. 910148-Superficies Minerales) for financial support. AFM growth experiments and SEM observations were carried out at the ICTS Centro Nacional de Microscopía Electrónica. X-ray diffraction measurements were conducted at the Centro de Difracción (UCM). This paper benefited from insightful comments by Eric H. Oelkers, Chen Zhu and three anonymous reviewers.

\section{REFERENCES}

Andrews J. E., Brimblecombe P., Jickells T. D., Liss P. S. and Reid B. (2004) An Introduction to Environmental Chemistry, 2nd ed. Blackwell Publishing.

Astilleros J. M., Pina C. M., Fernández-Díaz L. and Putnis A. (2003) Nanoscale growth of solids crystallising from multicomponent aqueous solutions. Surf. Sci. Lett. 545, L767-L773.

Bennema P. and Söhnel O. (1990) Interfacial surface tension for crytsallisation and precipitation from aqueous solutions. $J$. Cryst. Growth 102, 547-556.

Bernstein R. E., Betzer P. R., Feely R. A., Byrne R. H., Lamb M. F. and Michaels A. F. (1987) Acantharian fluxes and strontium to chlorinity ratios in the North Pacific Ocean. Science 237, $1490-1494$.

Bernstein R. E., Byrne R. H., Betzer P. R. and Greco A. M. (1992) Morphologies and transformations of celestite in seawater: The role of acantharians in strontium and barium geochemistry. Geochim. Cosmochim. Acta 56, 3273-3279.

Bernstein R. E., Byrne R. H. and Schijf J. (1998) Acantharians: A missing link in the oceanic biogeochemistry of barium. DeepSea Res. I. 45, 491-505.

Bernstein R. E. and Byrne R. H. (2004) Acantharians and marine barite. Mar. Chem. 86, 45-50.

Bishop J. K. B. (1988) The barite-opal-organic carbon association in oceanic particulate matter. Nature 331, 341-343.

Bokern D. G., Ducker W. A. C., Hunter K. A. and McGrath K. M. (2002) Surface imaging of a natural mineral surface using scanning-probe microscopy. J. Cryst. Growth 246, 139-149.

Bosbach D., Hall C. and Putnis A. (1998) Mineral precipitation and dissolution in aqueous solution: in situ microscopic observations on barite (001) with atomic force microscopy. Chem. Geol. 151, 143-160.

Carroll B. and Freeman E. (1954) The behavior of colloidal silicate solutions as revealed by adsorption indicators. J. Phys. Chem. 58, 335-338.

Chan L. H., Drummond D., Edmond J. M. and Grant B. (1977) On the barium data from the Atlantic GEOSECS expedition. Deep-Sea Res. I. 24, 613-649. 
Chow T. J. and Goldberg E. D. (1960) On the marine geochemistry of barium. Geochim. Cosmochim. Acta 20, 192-198.

Church T. M. and Wolgemuth K. (1972) Marine barite saturation. Earth Planet. Sci. Lett. 15, 35-44.

Dehairs F., Chesselet R. and Jedwab J. (1980) Discrete suspended particles of barite and the barium cycle in the open ocean. Earth Planet. Sci. Lett. 49, 528-550.

Dove P. M. and Craven C. M. (2005) Surface charge density on silica in alkali and alkaline earth chloride electrolyte solutions. Geochim. Cosmochim. Acta 69, 4963-24970.

Elhadj S., Salter E. A., Wierzbicki A., De Yoreo J. J., Han N. and Dove P. M. (2006) Peptide controls on calcite mineralization: polyaspartate chain length affects growth kinetics and acts as a stereochemical switch on morphology. Crystal Growth \& Design 6, 197-201.

Fernández-Díaz L., Putnis A. and Cumberbatch T. J. (1990) Barite nucleation kinetics and the effect of additives. Eur. J. Mineral. 2, 495-501.

Gan Y. (2009) Atomic and subnanometer resolution in ambient conditions by atomic force microscopy. Surf. Sci. Reports $\mathbf{6 4}$, 99-121.

Hay M. B., Workman R. K. and Manne S. (2003) Mechanisms of metal ion sorption on calcite: Composition mapping by lateral force microscopy. Langmuir 19, 3727-3740.

Higgins S. R. and Hu X. (2005) Self-inhibiting growth on dolomite: Experimental observations with in situ atomic force microscopy. Geochim. Cosmochim. Acta 69, 2085-2094.

Hollande A. and Martoja R. (1974) Identification du cristalloide des isospores de radiolaires a un cristal de celestite $\left(\mathrm{SrSO}_{4}\right)$. Détermination de la constitution du cristalloide par voie cytochimique et a l'aide de la microsonde électronique et du microanayseur par emission ionique secondaire. Protistologica 10, 603-609.

Horcas I., Fernández R., Gómez-Rodríguez J. M., Colchero J., Gómez-Herrero J. and Baró A. M. (2007) WSXM: A software for scanning probe microscopy and a tool for nanotechnology. Rev. Sci. Instrum. 78, 013705, 1-8.

Iler R. K. (1979) The Chemistry of Silica. Wiley, New York.

Isshiki K., Sohrin Y. and Nakayama E. (1991) Form of dissolved silicon in seawater. Marine Chemistry 32(1), 1-8.

Jones F., Radomirovic T. and Ogden M. I. (2012) Effect of solution silicate on the precipitation of barium bulfate. Cryst. Growth Des. 12(6), 3057-3065.

Kesler S. E. and Jones L. M. (1981) Sulfur and strontium-isotopic geochemistry of celestite, barite and gypsum from the Mesozoic basins of North Eastern Mexico. Chem. Geol. 31, 211-224.

Manoli F. and Dalas E. (2001) Calcium carbonate crytsallization in the presence of glutamic acid. J. Cryst. Growth. 222, 293-297.

Martinez J. R., Palomares S., Ortega-Zarzosa G., Ruiz F. and Chumakov Y. (2006) Rietveld refinement of amorphous SiO2 prepared via sol-gel method. Mater Lett. 60, 3526-3529.

Monnin C. and Cividini D. (2006) The saturation state of the world́s ocean with respect to $(\mathrm{Ba}, \mathrm{Sr}) \mathrm{SO}_{4}$ solid solutions. Geochim. Cosmochim. Acta 70, 3290-3298.

Monnin C., Jeandel C., Cattaldo T. and Dehairs F. (1999) The marine barite saturation state of the world's oceans. Mar. Chem. 65, 253-261.

Mullin J. W. (2001) Crystallization, 4th ed. Elsevier ButterworthsHeinemann.

Musić S., Filipović-Vinceković N. and Sekovanić L. (2011) Precipitation of amorphous $\mathrm{SiO}_{2}$ particle and their properties. Braz. J.Chem. Eng. 28, 89-94.
Odum H. T. (1951) Notes on the strontium content of sea water, celestite radiolaria, and strontianite snail shells. Science 114, 211-213.

Parkhurst D. L. and Appelo C. A. J. (1999) User's guide to PHREEQC (version 2). A computer program for speciation, batch-reaction, one-dimensional transport, and inverse geochemical calculations. USGS Water-Resources Investigation Report, 99-4259.

Paytan A., Kastner M., Campbell D. and Thiemens M. H. (1998) Sulfur isotopic composition of Cenozoic seawater sulfate. Science 282, 1459-1462.

Paytan A., Kastner M., Campbell D. and Thiemens M. H. (2004) Seawater sulfur isotope fluctuations in the Cretaceous. Science 304, 1663-1665.

Pina C. M., Enders M. and Putnis A. (2000) The composition of solid solutions crystallising from aqueous solutions: the influence of supersaturation and growth mechanisms. Chem. Geol. 168, 195-210.

Pina C. M., Putnis A. and Astilleros J. M. (2004) The growth mechanisms of solid solutions crystallising from aqueous solutions. Chem. Geol. 204, 145-161.

Pina C. M., Merkel C. and Jordan G. (2009) On the bimodal effects of silicic acids on calcite growth. Cryst. Growth Des. 9, 4084 4090.

Pina C. M. and Rico-García A. (2009) Nanoscale anglesite growth on the celestite (001) face. Surf. Sci. 603, 2708-2713.

Risthaus P., Bosbach D., Becker U. and Putnis A. (2001) Barite scale formation and dissolution at high ionic strength studied with atomic force microscopy. Colloids Surf. A Physicochem. Eng. Aspects 191, 201-214.

Risthaus P. (2003) Rasterkraftmikroskopische Untersuchungen zum Kristallwachstum von Baryt $\left(\mathrm{BaSO}_{4}\right)$ und isotyper Minerale: Mechanismen und Kinetik im molekularen Maßstab. Ph. thesis, Münster (in German).

Rushdi A. I., McManus J. and Collier R. W. (2000) Marine barite and celestite saturation in seawater. Mar. Chem. 69, 19-31.

Shindo H., Shitagami K., Kondo S. and Seo A. (1999) Atomic force microscopic observation of directional layer growth and dissolution on surfaces of sulfate minerals. J. Cryst. Growth 198(199), 253-257.

Siever R. (1957) The silica budget in the sedimentary cycle. Amer. Min. 42, 821-841.

Von Damm K. L. (1995) Controls on the chemistry and temporal variability of seafloor hydrothermal fluids. In Physical, Chemical, Biological, and Geological Interactions within Seafloor Hydrothermal Systems (eds. J. Lupton, L. Mullineaux and R. Zierenberg). Geophysical Monograph. 91, pp. 222-247. AGU.

Wojciechowski K. and Kibalczyc W. (1986) Light scattering study of $\mathrm{KH}_{2} \mathrm{PO}_{4}$ and $\mathrm{BaSO}_{4}$ nucleation process. J. Cryst. Growth 76, 379-382.

Wong S.-S., Takano H. and Porter M. D. (1998) Mapping orientation differences of terminal functional groups by friction force microscopy. Anal. Chem. 70, 5209-5212.

Wu W. and Nancollas G. H. (1998) Determination of interfacial tension from crystsallisation and dissolution data: a comparison with other methods. Adv. Colloid Interface Sci. 79, 229-279.

Zhang G., Xu Y., Xu D., Wang D., Xue Y. and Su W. (2008) Pressure-induced crystallization of amorphous $\mathrm{SiO}_{2}$ with silicon-hydroxy group and the quick síntesis of coesite under lower temperature. High Pressure Res. 28, 641-650. 